\title{
THE EFFECT OF FUNCTIONAL TRAINING, INTEGRITY, COMPETENCY AND ORGANIZATIONAL COMMITMENT OF QUALITY AUDIT IN THE AUDIT BOARD OF REPUBLIC INDONESIA
}

\author{
Edi Sunyoto* \\ The Audit Board Of Republic Indonesia* \\ big.edisunyoto@yahoo.co.id*
}

\begin{abstract}
*
This research investigate about the influence of functional training, integrity, competence and organizational commitment to quality audit. The purpose of this research was to determine the effect of functional training, integrity, competence and organizational commitment to quality audit, in The Audit Board of Republic Indonesia, Jakarta in 2017. The research used survey method quantitative approach with path analysis technique. Methods of survey research using quantitative approach path analysis techniques. The data were collected from 100 auditor as sample. Sample were sellected by simple random sampling from 130 Auditor as population. The results showed there is the significant direct effect functional of training on quality audit; integrity on qualty audit; competency on quality audit; organizational commitment on quality audit; functional training, Integrity and Competence significant direct effect on organizational commitment; functional training and Integrity significant direct effect on the competence; direct effect on the integrity of functional training is significant.
\end{abstract}

Keywords: functional training, integrity, competency, organizational commitment and quality audit.

The Audit Board of the Republic of Indonesia (BPK) as the government's external auditing agency has progressed significantly over the course of a decade. Since the promulgation of 3 (three) regulation packages in the field of state finance $(\mathrm{KN})$ and Law No. 15 of 2006 on BPK, the role and position of BPK is strengthened in terms of institutional / organization, scope of examination, employee, and budget to conduct KN examination. BPK in state finance governance has operational functions, recommendations and quasi judiciary. Operational and recommendation functions are a function of BPK to conduct state financial audits, and provide recommendations for improvement to other government entities / agencies. While the function of the judicial quasi BPK is to conduct a court of treasury demands which includes examining, examining, judging and deciding on the financial loss of the state caused by the treasurer.

Attention from stakeholders, on the BPK audit report (LHP) is increasing. The users of public financial statements (Akbar, 2013: 40-41) as stakeholders of public organizations include taxpayers, investors, creditors, fee-paying receipers, employees, suppliers, legislative councils, Oversight bodies, managers, and voters. BPK's opinion on LK of the central and regional governments as the main product of the institution that has been 
anticipated and noticed by representative institutions, the government and the general public. This is not separated because BPK has a very strategic role for the creation of efficient management of national resources.

BPK has a very important role in creating the efficiency of management of national resources. The maturity of the Audit Institution in a country can be seen from the position of achievement of the role in development as shown in Figure 1.1 (US GAO, 2007: 12). BPK as one of Intosai's members in addition to combating corruption, is now trying to move towards achieving the highest level of facilitating a facilitating foresight for the government in achieving the goals of the state.

The stakeholders as users of the audit report really want to know whether controls are being followed and whether their controls are working as planned. To find out it depends entirely on the report of the results of the examination. Therefore, the Public Accounting Firm or state audit institution (CPC, APIP) should be able to produce quality checks

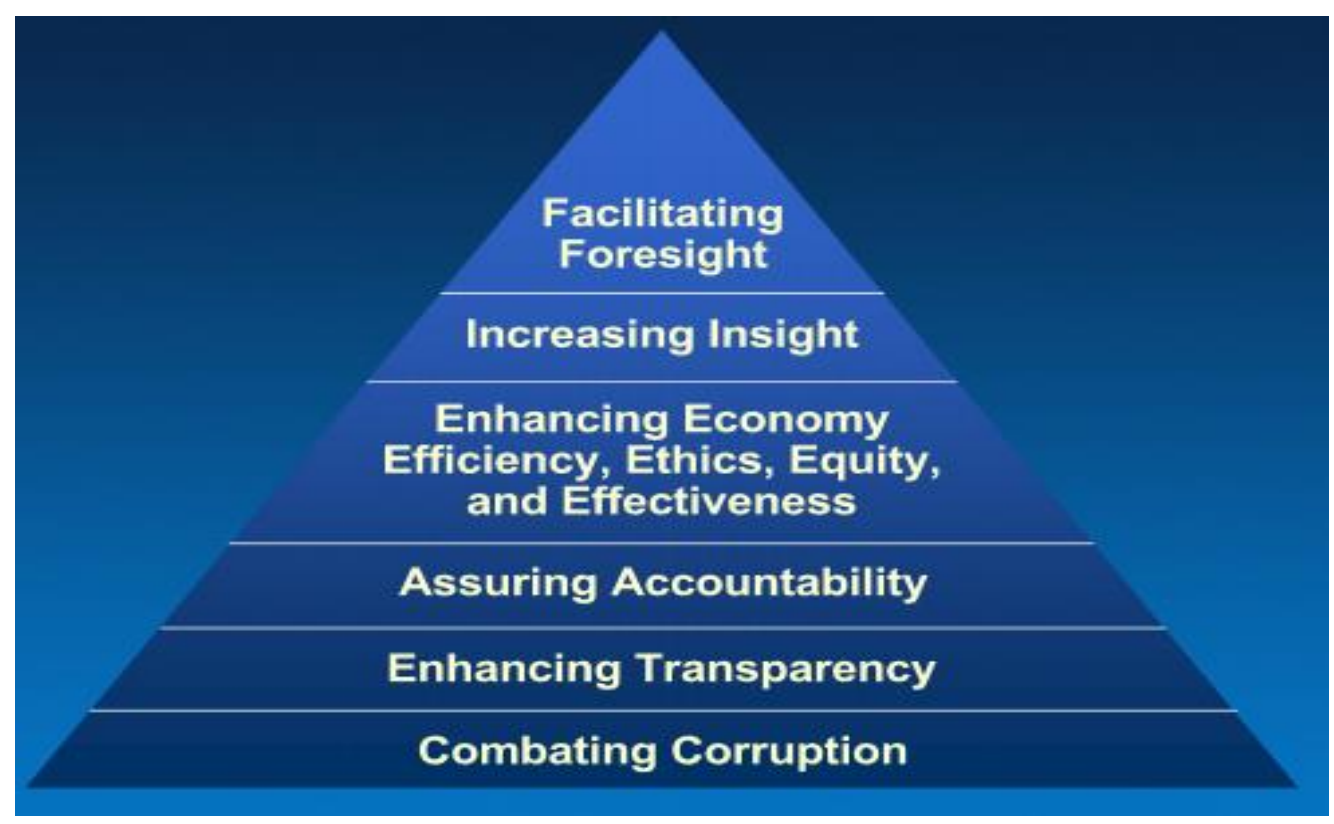

Figure 1.1 Accountability Organization Maturity Model Monitoring Agency According to Intosai

The background of this study is the first phenomenon of doubt by external parties (auditee and community groups) on the quality of BPK RI examination in the last few periods which can be seen from the demand of LHP, not fully completed monitoring of follow-up on the recommendation of result of inspection (TLRHP) and settlement Loss of state / region. The next reason is the increasing use of LHP BPK, and to carry out its strategic role and duties optimally, BPK is in desperate need of good quality human resources support at the top, middle and lower levels. In addition, the public also demands accountability for state management which includes financial accountability and 
performance accountability as one of the main fundamentals (accountability and transparency) in order to realize Good Governance (Akbar, 2013: 18-19).

Audit quality is a complex and multi-dimensional concept that not only deals with privat goods but also public good. Raaum and Morgan (2009: 303) "Quality is a complex concept with multiple meanings. "Fitness for uses," "conformance to requirements", "best for certain customer conditions," "and conformance to customer requirements" are four common definitions, ... ".

Quality in the context of public services (government / public services), then the demand for the needs of a service may arise because of political decisions established in a legislation or regulation. Therefore public service agencies should maintain the quality of their service products. BPK has set out in its vision and mission to actively contribute to the efficient and effective and economical and transparent and accountable public services and to provide "benefits" to the welfare of the people. Quality of examination is required as one form of accountability to the public and the profession on the management and accountability of state finances. The quality of the audit (De Angelo: 1981) is "The quality of audit services is defined to be the market-assessed joint probability that a given auditor will both find a breach in the client's accounting system, and (b) report the breach ".

The probability of finding violations depends on the auditor's technical ability and probability of reporting violations depending on the auditor's independence (Deis and Groux, 1992: 462-479). According to Arens, Beasley and Elder (2008: 105) the aspect of misstatement detection is a reflection of the auditor's competence, while reporting it is a reflection of the ethics or integrity of auditors, especially independence.

Several existing research results (De Angelo, 1981: 227-254, Deis \& Degrux, 1992: 462-479, Shockley, 1982: 785-800, Lennok, 1999: 779-805, and Dye, 1993; 887-914 ) It is known that there is a positive relationship between the auditor size and audit quality, in which the auditor size of some of the studies is stated as the auditor with more and more clients, the deeper pockets and the corresponding reputation of the auditor.

There are 4 (four) basic rules that must be met to realize the quality of audit (Arter, 2003: 19) ie the audit provides information for decision making, auditors are eligible to perform their duties, and measurements taken against the requirements specified, and the conclusions are based on fact. Furthermore, for performance audit (Arter 2003: 9-11) at least 3 (three) main issues that should be the attention of the compliance to the rules, the effectiveness of those rules for use; And suitability of the rules for achieving an organization's goals ". audit quality (US GAO 2015: 1) can be achieved if the audit is conducted under generally accepted auditing standards (GAAS) to provide reasonable assurance that the audited financial statements and related disclosures (1) are presented in 
accordance with GAAP and (2) not wrong Material misstatement whether by mistake or fraud.

Audit quality view as a system (Mills 1981: 1) that: "Audit Quality: a systematic and independent examination to determine whether the quality of activity and related results are comply whit planed arrangements and arrangements. Thus the quality of the examination can be seen from the operational inputs, processes, outcomes, outside environmental stresses on the implementation of the audit (PCAOB, 2013: 1-12). The desired audit results will be achieved more efficiently if the activities and associated resources are managed as a process (Arter, 2003: 40-54).

Training is every effort to improve the performance of employees for a particular job or skill improvement. Training is a process of teaching new / old employees with basic skills required / needed in a task (Dessler, 2011: 293-294) or any attempt to improve employee performance or a currently held job related (Bernardin \& Russell in Suwatno and Priansa , 2011: 118).

Trainning is a planned effort to facilitate the learning of job-related knowledge, skills, and behavior by employees" (Noe et al., 2011: 87-88) "(Noe et al., 2011: 87-88) or as learning that is provided in order to improve performance on the present job ( Nadler in Kirmani, 2015: 356-365). Integrity as the core value of the auditor's ethical code, then every examiner is required to adhere to standards of conduct (eg honesty and sincerity) in the course of his work and in the working relationship between them and the staff of the entity. Trust (Robbins, Judge and Hasham, 2012: 276-277) can be created by building integrity, competency, consistency, loyality, and oppenness.

The integrity of a person is reflected in, among other things, consistent maintenance of behavior with shared values (organization, profession), honest, ethical, and credible behavior, not otherwise inconsistent and immoral principles (Yukl, 2010: 56).

Competence as skill or ability (Roe in Bartram and Roe, 2005: 93-102) with explanation: duty or role. Typical for competences is that they integrates knowledge, skills, personal values and attitudes, and that they builds on knowledge and skills and are acquired through work experience and learning by doing.

Competence is the ability and willingness to perform tasks (Burgoyne, 1989: 56-57), competence is the behavioral dimension that affects performance (Woodruffe in Winterton, Deist and Stringfellow, 2006: 29-30). The competence values of an employee in the perspective of human resources development (HRM) can be fostered through education, development or training programs oriented to actual work demands with an emphasis on developing skills, knowledge, and abilities that will significantly provide standards Behavior in the system and work processes applied. 
Commitment (Brewer \& Hensher, 1998: 118) can be divided into three types namely organizational commitment, occupational commitment, and work commitment. Organizational commitment (Meyer \& Allen, 1991: 61-89) as a psychological state characterizing employee relationships with organizations, and having implications for the decision to continue or terminate membership in the organization. Organizational commitment from experts into three categories, namely the definition of affective orientation (affective orientation), based on cost (cost based), and obligation or moral responsibility (obligation or moral responsibility).

Robbins and Judge (2011: 74-75) that the commitment of a member to the organization in the form of "in organizational commitment, an employee identifies with a particular organization and its goals and wishes to remain a member." There are three elements of organizational commitment: Loyalty, alignment, and engagement. A person's involvement is formed because it is believed that the organization (Robbins and Coulter (2012: 377) as "the degree to which an employee identifies his or her job performance to be important to his or her self -worth. "

Kondalkar (2011: 92) completes in the definition of organizational commitment as follows: In other words, employees display an attitude of belonging to the organization, a sense of "MY" organization. They continue to do so even after they leave the organization. Of late a concept of organizational citizenship is used. It indicates a sense of belonging to a particular organization as if you were citizen of that organization, but it depends as to the contribution made by organization to have developed such feelings.

Thus affective commitment with regard to emotional attachment and will to survive with the organization; A normative commitment shows one's experience generating a sense of responsibility to endure; And continuance commitments reflect cost consciousness when linked decisions to leave the organization.

\section{METHOD}

This research uses quantitative approach through survey method and path analysis technique. The variables in this study consisted of endogenous variables of examination quality and exogenous variables of functional training, integrity, competence and organizational commitment. Data were collected through questionnaires from a population of 130 examiners and the sample used amounted to 100 examiners. Testing of data in this research is done through spreading questionnaire / questionnaire designed in the form of Linkert scale (for variebel Y, X1, X2, X4) and test model (Variable X3). Prior to the path analysis, conducted some testing requirements that must be met the data normality test, linearity test and regression significance test. All hypothesis testing using the real level $\alpha=$ 0.05 . 
This research was conducted at Head Office of BPK RI and BPK RI representatives. This location, with due consideration has never been done intensive and comprehensive research on the functional training, integrity, competence and organizational commitment to the quality inspection of functional officials examiners. The unit of analysis of this research is the examiner who acts as a member of the team in the thematic examination at Auditama Keuangan VI State during the period 2012-2016 as many as 130 examiners as the population. To fill out the questionnaire / questionnaire that is used as the respondent of the examiner 100 members of the examiner team as the unit of analysis. Special Instrument Variable quality inspection (Y) filled by 35 people who become the inspector team leader of the examiner team concerned. Research from the initial preparation stage, proposal formation, field research to research report was conducted from May 2015 to November 2016.

\section{RESULTS}

Data descriptions of each variable in this study are functional training, integrity, competence and organizational commitment to inspection quality. A common illustration of the condition of each variable uses descriptive statistics that include the centralizing and spreading of the data. Data centering measures include mean (mean), mode (mode) and median values. The size of the data spread includes the range of standard deviation (raw deviation) data and data variance. Measurements in the study were conducted on endogenous and exogenous variables. The endogenous variables in the study were examination quality (Y), while the exogenous variables in this study included functional training (X1), integrity (X2), competence (X3) and organizational commitment (X4). Hypothesis testing by using path analysis (path analys) used as a basis in answering the hypothesis can be described as follows.

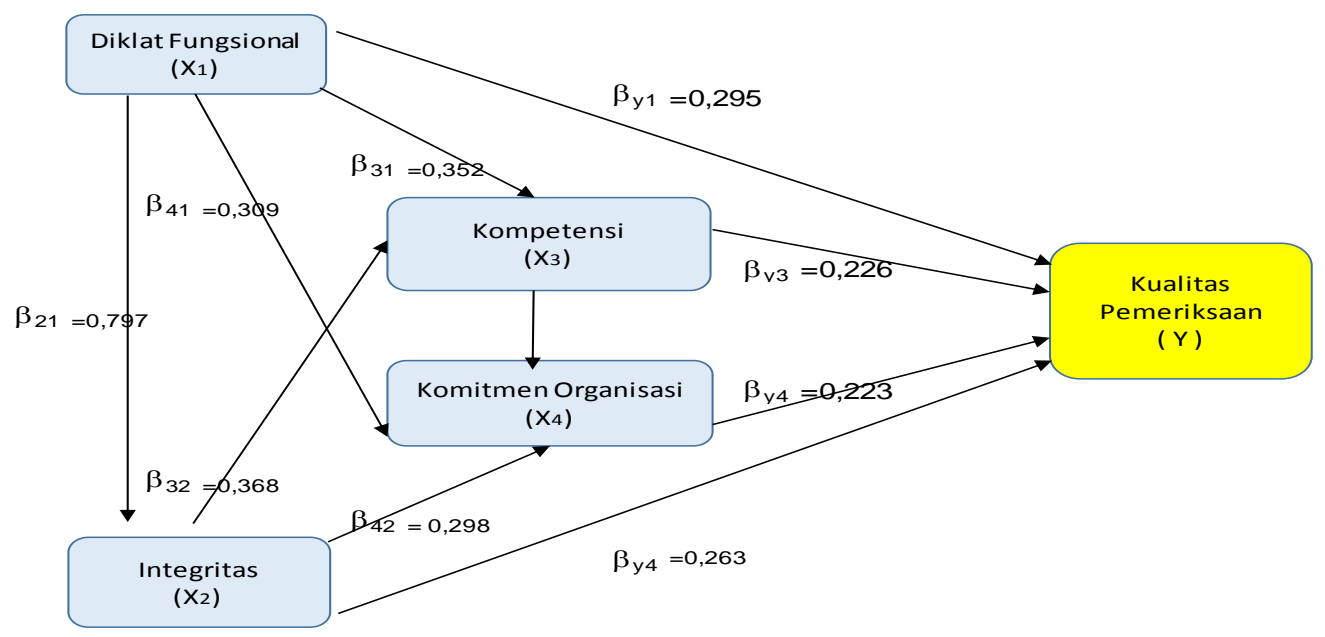

Figure 1 Coefficient Model of Paths X1, X2, X3 and X4 to Y 


\section{Research Hypothesis X1 to Y, X2 to Y, X3 to Y, and X4 to Y.}

Functional Training has a direct positive effect on the quality of the examination, integrity has a positive direct effect on the quality of the examination, the competence has a positive direct effect on the quality of the examination, and the organizational commitment has a positive direct effect on the quality of the examination. To be more clearly shown in table 1 .

Table 1. Coefficient of Influence of Functional Training on Quality of Inspection, Integrity to Quality Inspection, Competence to Quality Inspection and Organizational Commitment to Quality Inspection

\begin{tabular}{|c|c|c|c|c|c|c|c|c|}
\hline \multirow{2}{*}{\multicolumn{2}{|c|}{$\begin{array}{l}\text { Correlation } \\
\text { coofisience }\end{array}$}} & & \multirow{2}{*}{\multicolumn{2}{|c|}{$\begin{array}{c}\text { Path } \\
\text { co ofiecience }\end{array}$}} & \multirow[b]{2}{*}{$\mathrm{T}_{\text {count }}$} & \multicolumn{2}{|c|}{$\mathrm{t}_{\text {tabel }}$} & \multirow[b]{2}{*}{ Conclusion } \\
\hline & & & & & & & .01 & \\
\hline 1 & 11 & 0,8 & $\mathrm{y} 1$ & 295, & & & 63 & Significant \\
\hline $\mathrm{y}^{2}$ & & 0,8 & $\mathrm{y} 2$ & ,263 & & & ,63, & Significant \\
\hline $\mathrm{y} 3$ & 33 & 0,7 & $y_{0}$ &, 226 & $36^{*}$ & & ,63 & Significant \\
\hline 1 & 69 & 0,7 & y3 & ,223 & $98^{*}$ & & ,63 & Significan \\
\hline
\end{tabular}

\section{Information :}

*) Significant path coefficient (thitung $>$ ttable) at $\alpha=0.01$

Thus it can be concluded that improving the quality of examination is directly affected positively by improving the strength of functional training, integrity, competence and organizational commitment. Increased functional training, integrity, competence and organizational commitment lead to improved quality of examination.

\section{Research Hypothesis X1 to X4, X2 to X4, and X3 to X4.}

Functional Training has a direct positive effect on organizational commitment, integrity has a positive direct effect on organizational commitment, and competence has a positive direct effect on organizational commitment. For more details shown in table 2 below:

Table 2 Coefficient of Influence of Functional Training on Organizational Commitment, Integrity to Organizational Commitment, and Competence to Organizational Commitment 


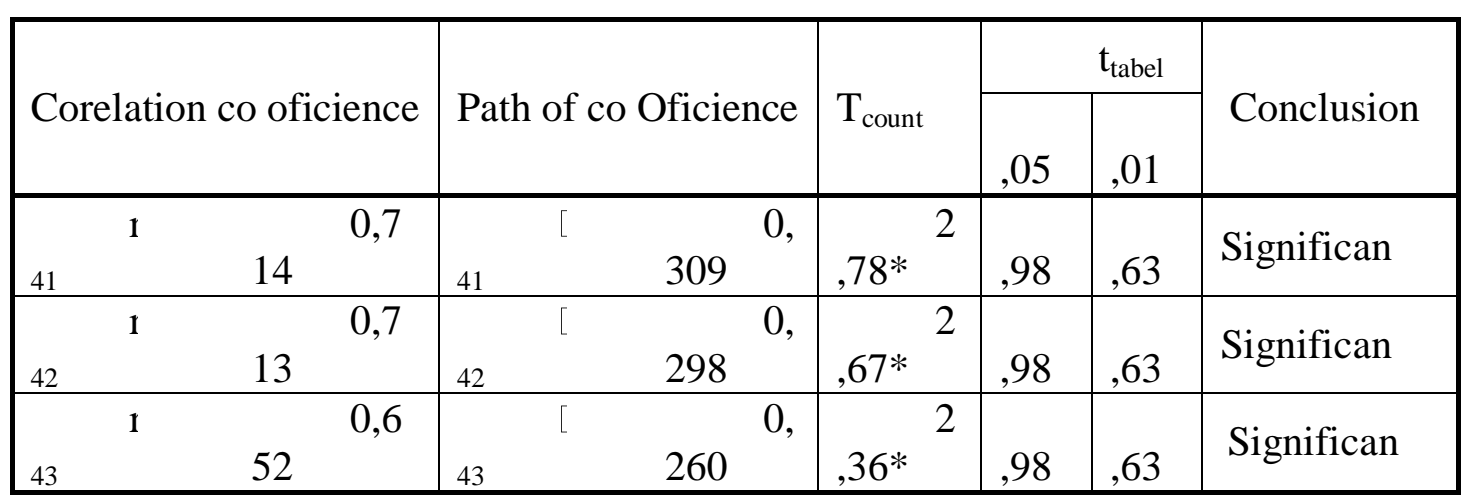

Information

*) Significant path coefficient (thitung> ttable) at $\alpha=0.01$

Thus it can be concluded that organizational commitment is directly affected positively by functional training, integrity, and competence. This means that the improvement of functional training, Integrity, and competence leads to an increase in organizational commitment

\section{Research Hypothesis X1 to X3, X2 to X3 and X1 to X2}

Functional training has a direct positive effect on competence, integrity has a positive direct effect on competence, and functional training has a direct positive effect on integrity. For more details shown in the following table

Table Coefficient of Influence of Functional Training on Competence, Integrity to Competence and Functional Training on Integrity

\begin{tabular}{|c|c|c|c|c|c|c|c|}
\hline \multirow{2}{*}{\multicolumn{2}{|c|}{ Corelation co oficience }} & \multirow{2}{*}{\multicolumn{2}{|c|}{ Path of co Oficience }} & \multirow{2}{*}{$\mathrm{T}_{\text {count }}$} & \multicolumn{2}{|c|}{$\mathrm{t}_{\text {tabel }}$} & \multirow{2}{*}{$\begin{array}{l}\text { Conclusio } \\
\mathrm{n}\end{array}$} \\
\hline & & & & & ,05 & ,01 & \\
\hline 31 & $45 \quad 0,6$ & 31 & $352^{0,}$ &, $86^{*}$ & ,99 & 63 & Significant \\
\hline 32 & $\begin{array}{ll} & 0,6 \\
48 & \\
\end{array}$ & 32 & 368 0 &, $99 *{ }^{2}$ & ,99 & ,63 & Significant \\
\hline 21 & 97 & 21 & $797 \quad$ & $3,06^{*}$ & ,99 & ,63 & Significant \\
\hline
\end{tabular}

Information :

**) Significant path coefficient (tCount $>$ ttabel) at $\alpha=0.01$

Thus it can be concluded that competence is directly affected positively by functional training and Integrity. Functional training affects integrity. This means that increased 
functional training, Integrity leads to increased competence of inspectors, and increased functional training resulting in increased integrity of BPK auditors.

\section{DISCUSSION}

The detailed discussion of the results of analysis and testing statistically by using path analysis (path analysis) on the research hypothesis is described as follows:

\section{Effect of Functional Training on Quality Inspection}

The test results are known that Functional Training is a direct positive influence on Quality Inspection. This study is in accordance with the latest developments in the world related to the issue of Total Quality Management (TQM). Quality of examination (De Angelo, 1981 183-199) is largely determined by the auditor's ability to detect errors largely determined by competence and experience. The competence of the examiner is largely measured by the knowledge that an inspector can obtain through education, training and experience during the examiner. According Amstrong (2009: 665) that training involve the applications of formal processes to impart knowledge and help people to acquire the skills form them to perform their jobs satisfactory.

Inspection tasks are collective work by involving individuals with various educational backgrounds. Individuals should set aside personal rights and contribute to groups, therefore they should be recruited appropriately and programmed to follow the required technical training on an ongoing basis. Konopsaske et al. (2009: 253) teamwork will be more successful or fail is dependent on "on the amount, intensity, and duration of training they receive.

\section{The influence of integrity on the quality of examination}

Based on the test results can be concluded that there is a direct positive influence of Integrity to Quality Inspection. Although different from the results of research Sukriah, Akram and Adha (2009: 21) that integrity has no significant effect on audit quality. But the facts in the field is still going on a bribery process involving law enforcement officers and auditors. It proves that the risk of individual, management and corporate fraud is very high and an independent audit is required. Although Colquit, Scott and LePine (2009: 240) explain that: trust has a moderate positive effect on performance. Employee who are willing to be vulnerable to aotorities tend to have heigherlevels of task performance.

However, BPK employees must be able to maintain public trust (Robbins, Judge and Hasham, 2012: 276-277) by building integrity, competency, consistency, loyality, and 
oppenness. Comparative research on human capital public-sector policy (Dwiputrianti and Sanusi, 2011: 1) shows the public expectation and complaints about the low quality of public services in Indonesia, among others, due to under-standard employee competence, poor civil servant recruitment system and lack of awareness of and obligation (integrity low)

Because the integrity of the examiner is very important to be maintained and improved, as an effort to build character and competence in the framework of enforcing civil servant integrity reform. Integrity that has been built must be maintained, because a little bit violated will have a direct impact on the decline in public confidence.

\section{The influence of competence on the quality of examination}

The test results show there is a direct positive influence of competence on the quality of examination. This is particularly relevant to the audit quality dimension De Angelo (1981: 183-199) has depended on depending on competence and independence. The probability of finding violations depends on the auditor's technical ability and probability of reporting violations depending on the auditor's independence (Deis and Groux, 1992: 462-479). Duration of the audit, audit period, auditor experience, and review of third parties is the longest determinant of audit quality. Boner and Walker (1994: 157-178) concluded that a competent Auditor would encourage the creation of good quality of the audit process.

Experienced auditors have a significant error rate compared to more experienced auditors (Wright in Sarwono and Agoes, 2014: 278-181). The SPKN requires the fulfillment of the skill / capability of the examiner and if the assistant is to be supervised. Boner and Walker (1994: 157-178) concluded that a competent Auditor would encourage the creation of good quality of the audit process.

Increased competence through the empowerment of examiners will be meaningful when it can encourage the improvement of service quality over state financial audits, which can be attained by "Achieving Commercial Outcomes, Delivering Value for Money, Managing a Quality Service Delivering at Pace" (UK Government: 2012, 1-5 ). A strict inspection schedule as an inherent inherent risk, the examiner must have the expertise to devise an effective plan, manage and manage the time and activities to provide high quality, safe, reliable and efficient services, implement programs / projects and risk management that are integrated as Approach to support services. Leaders of public institutions should open the horizon to create an environment for "delivering operational excellence and creating the most appropriate and cost effective delivery models" in every public service 


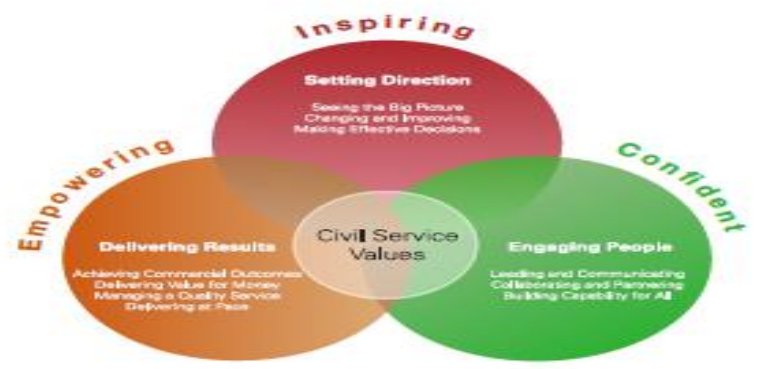

figure 2. Frame Work Pengembangan Civil Service Competence melalui Empowering.

Thus the improvement of competence is very important, in addition to audit fees and professional commitment to produce quality services.

\section{Effect of organizational commitment to the quality of examination}

The results of statistical tests show that there is a direct positive influence of organizational commitment to the quality of the examination. There are three main factors (strategic, functional, workplace) that affect organizational commitment. At the "workplace" level of organizational commitment is influenced by selection based on "high standards", extensive work design and teamwork, employee engagement in problem solving, cooperative climate and trust (Kochan and Dyer in Armstrong, 2009: 349-350).

Commitment (Avkiran, 1999: 67-74) as a dynamic concept and a prerequisite for the establishment of the credibility of an organization without which an organization will lose its reputation. Involvement in teamwork will result in good performance if each individual on the team has put and earned trust. Trust has a direct positive impact on commitment (Walter, Mueler and Helfert, 1999: 1-5). Independent attitude and integrity is a manifestation of the auditor's commitment to the organization that simultaneously impact on the quality of its audit. An effective team is the key to successful examination. Therefore every inspector must have a unified commitment characterized by a strong dedication to the team's goals and willingness to assist the team's success (Kirkman, Ghibson and Shapiro in Robbins and Couter, 2012: 359-360).

\section{Effect of functional training on organizational commitment}

The results of statistical tests show that there is a positive direct effect of the functional training on the organization's commitment. The CPB as one of the state organizers with the state financial examiner tupoksi is required to be a dynamic organization because the environment is constantly changing, so the mindset to think far ahead should be maintained and enhanced by the employees working in CPC. 
To realize the BPK as a learning organization, the functional training in addition to improving skills and knowledge, as well as influencing creative / innovation culture, can also influence the growth of organizational commitment to the training participants. One of the objectives of the training is to internalize the training participants in order to contribute directly or indirectly in realizing organizational goals. The training will have implications for the creation of a more conducive working environment, so that members of the organization become more solid. Ivancevich and Konopaske (2013: 395) define training as a systematic process of changing employee behavior in a direction that will achieve organizational goals

This is consistent with the research of Pak (2007: v-vi) "Organizational commitment and job satisfaction are also positively related to the performance of organizational learning and work performance. Research on HRM practices in India such as training \& employee development, compensation and welfare activities have a significant impact on organizational commitment and are associated with superior organizational performance (Lamba and Choudhary, 2013: 407-423). So training can shape the behavior of employees in achieving organizational goals and objectives of the employees concerned.

\section{The influence of integrity on organizational commitment}

The results of statistical calculations show there is a direct positive influence of integrity to organizational commitment. Auditors in conducting audits should uphold the integrity reflected in an honest, courageous, thoughtful and responsible manner. These four elements are needed to build trust and provide the basis for reliable decision-making.

Establishing trusts as a result of the application of integrity, can affect work commitment. Colquitt, LePine and Wesson (: 240) say that "trust has a strong positive effect on commitment. Trust grows from the application of high integrity, can increase employees' commitment to the organization. It is as described Dirks and Ferrin in Colquitt, LePine and Wesson (2009: 241) because, one reason is that trusting an authority increase the likelihood that an emotional bond will developed, particulary if that trust is rooted in positive feelings for authority.

Bitner and Brown (2008: 39-46) emphasize that the success of an employee is essentially those who have a certain depth of knowledge and understanding of their commitment who must cooperate to succeed by interacting complex / diverse within an organization / community. So people who integrity will mengimplentasikannya in the form of a commitment to participate in organizational achievement activities.

\section{The influence of competence on organizational commitment}

The results of statistical tests show that competence has a positive direct effect on organizational commitment. A person's commitment to something is essentially an agreement to do something good for yourself, others, group or organization. Robbins and Coulter (2007: 377) an organization member will actively participate and show that his 
involvement becomes important and valuable. In order to be able to contribute optimally in the organization, then one must have certain competencies. Kochan and Dyer cited Armstrong (2009:) at a "workplace" level of organizational commitment influenced by selection based on "high standards", extensive work design and teamwork, employee engagement in problem solving, cooperative climate and trust.

High standards include the provision of certain conditions to become members of an organization. BPK as a public sector audit institution, has a competency standard to be able to be appointed / occupied a certain role in JFP. Even BPK has used an assessment center for the mapping process of the competency of the skills of each employee. Currently BPK is designing the concept of competency-based employee development, which will be linked to career development and employee mutation patterns.

\section{Effect of functional training on competence}

The result of path analysis, showed the positive direct effect of Functional Training on the competence of Auditors in BPK RI. The existence of civil servants in the era of regional autonomy and reform has a very strategic position, because the success of governance and public service, is highly dependent on the competence of civil servants. The paradigm shift in governance from "rule government" to "good governance" or "from government to governance", from centralized to decentralized, must be balanced with the paradigm shift from the bureaucratic mindset (birocrat) to service and supported by competent civil servants Adequate and in accordance with the demands of the task.

Each state civil apparatus is required to provide the best public service in its field as an integral part of good governance. Competence of civil servants is related to the ability in the form of knowledge, skills, skills, attitudes and behavior required in the implementation of the main tasks, functions of authority and responsibility mandated to him.

The results of the WERS 2013 survey (Wanrooy et al. In Torrington et al .: 2014: 277) show that the highest level of training is in the public sector and larger organizations, especially those with high professional professional levels. Accountants therefore need a variety of skills in order to succeed, because the existing curriculum is not enough to build accountant success, training is still needed through advanced professional education courses (Eynon in Noviyani and Bandi, 2002: 9). The experience gained from certain specialized programs has a greater impact on skills improvement than traditional programs (Boner and Walker: 1994: 157-178).

In order for the inspection team to be effective, it will require personnel with relevant skills (Robbins and Coulter, 2009: 360). Management experts believe that training is useful for improving staff professionals. Hayes and Ninemeier (2009: 175) remind us of the importance of training for every profession, because "professionals want to do their job as best they can, and this is only possible with appropriate training". 


\section{Influence of integrity to competence}

The result of path analysis, shows that there is a direct positive influence of integrity to competence. The integrity of the auditor establishes trust and provides the basis for reliance on public judgment on auditor behavior. The Implementation of the Integrity of the Auditor is manifested by the attainment of their work with honesty, diligence, and responsibility, protecting their independence and not receiving gratification gifts that may affect, compromise or threaten the auditor's ability to act and be seen to act independently, observe the applicable law and make disclosure Which is expected by law and profession; Pay attention to the audit process.

In the era of globalization ethical-related issues become something that must be considered for the organization to compete and win the competition elegantly. To lead the organization from the tough times of servant ledearship requires 10 characteristics of one Awareness. Awareness includes understands issues involving ethics and values; Can view most situations from a more integrated, holistic position (Arkin in Torrington et al., 2014: 224).

While Competence describes what is needed so that he is able to carry out his work well (Armstrong and Baron, 2009; 208-209). An examiner will prove himself as a person of integrity in a variety of elegant and ethical ways such as improving his ability, so as to have the minimum required competencies.

\section{Effect of functional training on integrity}

Based on the results of the calculation there is a positive direct effect of functional training on integrity. The roots of self-confidence as a community servant are: conscious living habits, accepting habits, self-responsible habits, defending rights, living habits with purpose, and "personal integrity habits" (Robbins 1994: 34).

Training is useful for employees to improve morale (Hayes and Ninemeier: 2009: 175), because "Training can help staff members feel good about themselves and their employers. These positive attitudes can have a significant influence on the overall preceptions of the workplace. "

In the functional training of examiners, participants will get input from instructors and other participants who can grow the seeds of personal integrity that support the value and culture of the organization. According to Rivai (2004: 215), the benefits of training activities can be grouped into three categories: benefits for employees (individuals), firms, and benefits in human resources, intra and intergroup relationships and policy implementers. This is in line with Simamora's (2002) opinion that auditor expertise is 
determined by: formal scholarship education; Training and experience in auditing and public accounting; Participation in continuing education programs during professional careers.

One of the impacts of training for participants is a comprehensive understanding of a problem. In the training-related training on the formation of behavior, it helps the auditor understand and take a professional attitude, based on the future thinking of the impact that arises in taking the conclusions and recommendations. In an era of openness of something good, if not delivered properly and appropriately it will be at risk of causing the habit of the root of the problem. Because the examiner must be integrity in speech and deeds.

This research provides suggestions and recommendations (1) efforts to improve functional training program for examiners by conducting systematic, comprehensive and holistic training needs assessment by empowering BPK assessment center as assessment of knowledge in the planning stage up to evaluation. Training programs are not just held but must be in line with the vision, mission and strategic objectives of the body, and to support efforts to improve the quality of the examination. (2) Improving the integrity of the examiner needs to be done thoroughly so that all inspectors in the organization have the spirit to give their best efforts in working. Bureaucracy reform in BPK RI must be able to create role model of public service that is accountable, transparent in management and state finance responsibility. The training materials cover the implementation of integrity and its impact on individuals and organizations. (3). Development of employee competency on talent based assessment result with talent search matrix method to support examination task, mutation pattern and career coaching and employee development. (4). To increase the commitment of the organization, it is necessary to develop technical and supporting technical synergy for the achievement of quality inspection and human capital development based on Human Capital Mangement is a must to be implemented.

\section{CONCLUSION}

From the results of the analysis and discussion that has been described then the conclusions of this study as follows:

Improving the quality of the examination is directly affected positively by increased participation of functional training, integrity, competence and organizational commitment. Increased functional training, integrity, competence and organizational commitment lead to improved quality of examination. Organizational commitment is directly affected positively by functional training, integrity, and competence. This means that increased functional training, Integrity, and competence resulted in increased organizational commitment of auditors in BPK RI. Increased functional training, integrity leads to increased competence of examiners, and increased functional training resulting in 
improved integrity of examiners. It means an effective training improvement followed by examiners, increased integrity resulting in increased competence of examiners. Training funsion

\section{REFERENCES}

Agoes, Sukrisno Auditing (Pemeriksaan Akuntan) oleh Kantor Akuntan PublikEdisi Kedua.Jakarta: Lembaga Penerbit-FE UI, 1999. 2013.

Akbar, Bahrullah, Akuntansi Pemerintahan. Jakarta: CV. Bumi Metro Raya,

Akbar, Bahrullah, Akuntansi Sektor Publik Konsep dan Teori. Jakarta: CV. Bumi Metro Raya, 2013.

Anderson, Eugene W., Claes Fornell, dan Donald R. Lehmann, Customer Satisfaction, Market Share, and Profitability: Findings from Sweden. Journal of Marketing, Vol. 58, No 3 (Jul., 1994 diterbitkan kembai 12 April 2006 ), https://www.jstor.org/ (diakses tanggal 17 Mei 2015).

Annesa Andriyani, Andreas dan Hardi, Analisis Pengaruh Tingkat Pendidikan, Kecakapan Profesional, Pendidikan Berkelanjutan, Independensi, Kepatuhan pada Kode Etik Terhadap Kualitas Hasil Pemeriksaan dan Pengalaman Kerja Sebagai Variabel moderating, Jurnal Akuntansi Keuangan dan Bisnis Vol. 6, Desember 2013, 10-18, Magister Akuntansi Unri, http://journal.pcr.ac.id/paper (diakses tanggal 1 Juni 2014).

Arens, Alvin A., Mark Beasley, dan Randal J. Elder: Auditing and Assurance Service. Twelfth Edition. Pearson Education International, 2008.

Arikunto, Suharsimi: Prosedur Penelitian: Suatu Pendekatan Praktik. Jakarta: PT. Rineka Cipta, 2013.

Armstrong, Michael: Amstrong's handbook of Human Resource of Management Practice. London and Philadelphia: Kogan Page, 2009.

Armstrong, Michael: Amstrong's handbook of Performance Management An evidence-based guide to delivering high performance. London and Philadelphia: Kogan Page, 2009.

Armstrong, Michael, Baron, Angela, Strategic HRM: The Key To Improved Business Performance. CIPD, London, p.xviii, 2003.

Arter, Dennis R., Quality Audit For Improved Performance -Third Edition. New York: ASQ Quality Press, 2003.

Avkiran, N.K., "Quality Customer Service Demands Human Contact", The International Journal of Bank Marketing, Vol. 17 No. 2. 1999, http://ijbssnet.com/journals (diakses 15 September 2016).

Brewer, Ann M. and David A. Hensher, The Importance of Organisational Commitment in Managing Change: Experience of the NSW Private Bus Industry, Logistics and Transportation Review, Vol. 34, No. 2, 1998, h. 118 (diakses tanggal 8 Nopember 2014).

Charles A, Mills: The Quality Audit A Management Evaluation Tool. New York: McGraww-Hill, 1989.

Colquitt, Jason, A., Jeffery A. Le Pine, and Michael J. Wesson. Organizational Behavior: Improving Performance and Commitment in the Workplace. Southern Gate: 
John Weley \& sons.Ltd, 2009.

Covey, Stephen R, A. Roger Merryll dan Rabecca R. Merryll, First Things First: To Live, to Love, to Learn, to Leave a Legacy. New York: Simon \& Schuster,2010.

De Angelo, Linda Elizabeth, "Auditor size and audit quality". Journal of Accounting and Economics 3, 183-199, http://wlkc.gdqy.edu.cn North-Holland Publishing Company, 1981. (diakses tanggal 1 Juni 2014).

De Angelo, H., DeAngelo, L., Stulz, R., Dividend policy and the earned/contributed capital mix: a test of the life-cycle theory. Journal of Financial Economics, 227-254, 2006. (diakses tanggal 1 Juni 2014)

Deis, Donald, R., Jr dan G.A. Giroux, Determinants of Audit Quality in the Public Sector. The Jurnal Accounting Review, 67, 3, 462-479.,1992. (diakses tanggal 1 Juni 2014).

Dessler, Garry, Human Resource Managementh Twelfth Edition. London: Pearson, 2011.

Dye, R., Auditing Standards, Legal Liability and Auditor Wealth, Journal of Political Economy, 1993. Vol.101 (diakses tanggal 1 Juni 2014).

Francis, J. R., A Framework for Understanding and Researching Audit Quality. Auditing: A Journal of Practice \& Theory 30(2), 2011, 125-152. (diakses tanggal 1 Juni 2014).

F. Longo \& D. Cristofoli, Strategic Change Management in the Public sector-An EFMD European Case Book. (England: John Weley \& sons.Ltd, 2007.

Hebert, Leo. Auditing the Performance of Management California: Lifetime Learning Publications-A divisions of Wadsworth, inc, 1979). p. 19.

Ivancevich, John M. dan Robert Konopaske, Human Resource Management Twelfth Edition. Singapore: Mcgraw-Hill/Irwin, 2013.

Jason, A. Colquitt, Jeffery A. Le Pine, and Michael J. Wesson. Organizational Behavior: Improving Performance and Commitment in the Workplace. Southern Gate: John Weley \& sons.Ltd, 2009.

Juran, Joseph M. dan A. Blanton Godfrey, Juran's Quality Handbook, Fifth Edition. New York: McGraw-Hill:1999.

Konrath, Larry F., Auditing: A Risk Analysis Approach $-5^{\text {th }}$ Edition. Canada: South-Western, 2002

Knowles, Graeme, Quality Management. London:Ventus Publishing ApS, 2011.

Lamba, Shruti \& Nirmala Choudhary, Impact of HRM Practices on Organizational Commitment of Employees, in International Journal of Advancements in Research \& Technology, http://www.ijoart.org/docs (diakses 15 Oktober 2016).

Lennox, S. Clive, Audit Quality \& Auditor Size: An Evaluation of Reputation and Deep Pockets Hypotheses. Journal of Business Finance \& Accounting, 26(7) \& (8), Sept/Oct, 1999 (diakses tanggal 13 Juli 2014).

Mathis, Roberth L. and John H. Jakson, Human Resource Managemet. Mason: South-Western, 2011.

Mathis, Robert L. dan John H. Jakcson, Manajemen Sumber Daya Manusia Jakarta: Salemba Empat, 2002.

McClelland, David. C. Testing for competence rather than for "intelligence." American Psychologist, 28, 1-14, 1973, http://mohandasmohandas.com/ /african1/ap7301001(1).pdf (diakses tanggal 26 Oktober 2014). 
McShane, Steven L. \& Mary Ann Von Glinow,, Organizational Behavior (New York: Mcgraw -Hill International Edition, 2013), h. 383.

Meyer, JP and Natalie J. Allen, "A three-component conceptualization of organizational commitment: Some methodological considerations"-Human Resource Management Review, 1, pp. 61-98, 2007 (diakses tanggal 8 Nopember 2014).

Meyer, Jopn H. and Natalie J. Allen, Commitment in The Workplace: Theory, Research, and Application. California: SAGE Publications, Inc., 1997.

Meyer, Jopn H., Laura J. Stanley, dan Natalya M. Parfyonova, Employee commitment in context: The nature and implication of commitment profiles", Journal of Vocational Behavior, 80, 2012. (diakses tanggal 8 Nopember 2015).

Mills, Charles, Quality audit: A Management Evaluation Tool, New York: MC Graw-Hill, 1989.

Noe, Raymond A. et al., Human Resource Management " Gaining a Competitive Advantage” Seven Edition New York: McGraw-Hill/Irwin, 2010.

Noe, Raymond A. et al., Foundamental of: Human Resource Management " Gaining a Competitive Advantage" Fourth Edition New York: McGraw-Hill/Irwin, 2011.

Vincent K., Omachonu, dan Ross, Joel E., Principles of Total Quality, Third.

Öhman, P., E. Häckner, and D. Sörbom, Client satisfaction and usefulness to external stakeholders from an audit client perspective. In Managerial Auditing Journal 2012, http://www.emeraldinsight.com/ (diakses 15 Juli 2015)

Owoyemi, Oluwakemi Ayodeji. Michael Oyelere, dan Tunde Elegbede, "Enhancing Employees' Commitment to Organisation through Training": International Journal of Business and Management, Vol. 6, No. 7 July 2011. www.ccsenet.org/ijbm. (diakses 11 November 2014).

Raaum, Ronell B. \& Stephen L. Morgan, Performance Auditing: A Measurement Approach-2 $^{\text {nd }}$ Edition. New York: The Institute if Internal Auditor-Research Foundation, 2009.

Rivai, Vithzal, Manajemen Sumber Daya Manusia Untuk Perusahaan. Jakarta: PT Raja Grafindo Persada, 2004.

Robbins, Stephen P. Perilaku Organisasi. Jakarta: PT.Indeks, 2007.

Robbins, Stephen T., Timothy A. Judge \& Elham S. Hasham, Organizational Behavior, The Arab World Adaptation Edition. London: Pearson Education Ltd, 2012.

Robbins Stephen P. dan Marry Coulter, Management, $11^{\text {th }}$ edition. New Jersey: Pearson Education Inc., 2012.

Sarwono, Iman dan Agoes Sukrisno. An empirical analysis of auditor's industry specialization, auditor's independence and audit procedures on audit quality: Evidence from Indonesia, International Conference on Accounting Studies 2014, ICAS 2014, 18 19 August 2014, Kuala Lumpur, Malaysia, Procedia Social and Behavioral Sciences 164 ( 2014 ), pp. 271 - 281 http://ac.els-cdn.com/S1877042814058972 (diakses tanggal 13 Juli 2014).

Simamora, Henry, Auditing. Yogyakarta: Bagian Penerbitan STIE YKPN, 2004.

Stephen P. Robbins \& Timothy A. Judge, Organizational Behavior.New Jersey: Pearson Education, Inc., 2011.

Shockley, R.A, Perceptions of Audit Independence: A Conceptual Model. Journal of Accounting, Auditing \& Finance 5, 1982. http://connection.ebscohost.com/c /articles 
(diakses tanggal 13 Juli 2014).

Spencer \& Spencer, 1993, Competence at Work: Models for Superior Performance. Canada: John Wiley \& Sons, Inc, 1993.

Sugiyono, Metode Penelitian Bisnis: Pendekatan Kuantitatif, Kualitatif dan R\&D, Cetakan ke-3. Bandung: CV Alfabeta, 2009.

Sukriah Ika, Akram dan Inapty Biana Adha. Pengaruh Pengalaman Kerja, Independensi, Objektivitas, Integritas dan Kompetensi Terhadap Kualitas Hasil Pemeriksaan. Jurnal (diakses 1 Juli 2014).

Suwatno dan Donni Juni Priansa, Manajemen SDM dalam Organisasi Publik dan Bisnis. Bandung: Alfabeta, 2011.

Torrington, Derek, et. al., Human Resource Management. London: Pearson Education Limited, 2014.

Tuanakotta, TM; berfikir kritis dalam auditing. Jakarta, Salemba Empat, 2011

Truss, Catherine et al: Strategic Human Reource Management. Oxford: Oxford University Press, 2012.

Winterton, Jonathan Francoise Delamare, dan Le Deist Emma Stringfellow, Typology Of Knowledge, Skills And Competences: Clarification Of The Concept And Prototype (Luxembourg: Office for Official Publications of the European Communities, 2006), h. 29. (diakses tanggal 17 Mei 2015)

\section{Rules of Law:}

Yukl, Gary: Leadership in organization. New Jearsey:Pearson Printice Hall, 2010. Undang-Undang Nomor 17 Tahun 2003 Tentang Keuangan Negara.

Undang-Undang Nomor 1 Tahun 2004 Tentang Perbendaharaan.

Undang-Undang Nomor 15 Tahun 2004 Tentang Pemeriksaan Pengelolaan dan Tanggung Jawab Keuangan Negara.

Undang-Undang Nomor 15 Tahun 2006 Tentang Badan Pemeriksa Keuangan.

Peraturan Pemerintah Nomor 101 Tahun 2000 tentang Pendidikan dan Pelatihan Jabatan Pegawai Negeri Sipil.

Hongkong Institute of Certified Public Accountants, www.hkicpa.org.hk (diakses tanggal 29 Mei 2014).

INTOSAI : Professional Standards Committee : Code of Ethics.

The US Government Accountability Office: Standing Advisory Group Meeting Discussion-Audit Quality Indicators. Public Company Accounting Oversight Board (PCAOB), PCAOB Release May 15-16, 2013.

The US Government Accountability Office: Concept Release On Audit Quality Indicators/Potential Audit Quality Indicators. Public Company Accounting Oversight Board (PCAOB), PCAOB Release No. 2015-005 July 1, 2015.

UK Government, Civil Service Competency Framework 2012-2017, (Londonn: Civil Service Human Resource, http://www.gov.uk/ government (diakses 1 Januari 2016). 